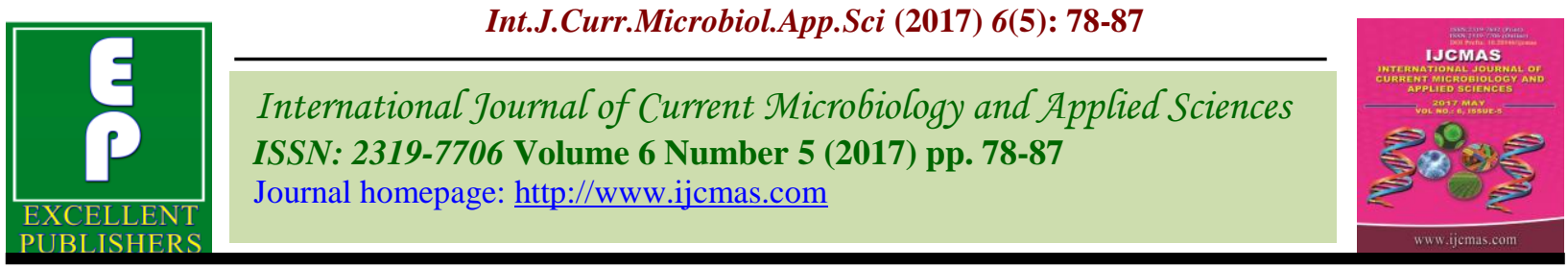

Review Article

https://doi.org/10.20546/ijcmas.2017.605.010

\title{
Diversity of Tomato Leaf Curl Virus (Tolcv), Bemisia tabaci and its Transmission
}

\author{
Ratan Das $^{1 *}$, Rajen Chowdhury ${ }^{2}$, Ashutosh $\operatorname{Singh}^{3}$ and Susmita Sarkar \\ ${ }^{1}$ Department of Horticulture and Post Harvest Technology Visva-Bharati, India \\ ${ }^{2}$ Department of Biotechnology, CPMB\&B, Tamil Nadu Agricultural University, India \\ ${ }^{3}$ Department of Plant Biotechnology UAS GKVK Bengaluru, India \\ ${ }^{4}$ ICAR, Tripura, India \\ *Corresponding author
}

\begin{tabular}{|c|c|}
\hline & A B S T R A C T \\
\hline $\begin{array}{l}\text { ToLCV, } \\
\text { Bemisia tabaci, } \\
\text { Transmission. }\end{array}$ & \multirow{3}{*}{$\begin{array}{l}\text { Tomato leaf curl virus (ToLCV) is a very important pathogen in the tomato grown belt of } \\
\text { India and world as a whole. It persist wide diversity and many isolate has been identified } \\
\text { however molecular marker has represented its usability for the same. ToLCV can't } \\
\text { transmit by itself, it require a vector for the transmission and Bemisia tabaci serve the } \\
\text { purpose. This vector has a vast host range and show a wide diversity. Many biotypes were } \\
\text { identified based on their morphological characteristics and RAPD-PCR analysis viz B, Q, } \\
\mathrm{Cv} \text { biotypes. For transmission virus vector relation is very important and Begomo viruses } \\
\text { has only one vector that is } B \text {. tabaci because of a chaperone GroEL protein that binds the } \\
\text { virus particles and protects them from degradation in gut and hemolymph however number } \\
\text { of vector, Acquisition access period, plant age etc. also equally important for the effective } \\
\text { transmission. }\end{array}$} \\
\hline Article Info & \\
\hline $\begin{array}{l}\text { Accepted: } \\
\text { 04 April } 2017 \\
\text { Available Online: } \\
\text { 10 May } 2017\end{array}$ & \\
\hline
\end{tabular}

\section{Introduction}

Among the many virus diseases affecting tomato crop tomato leaf curl virus (Geminivirus: Sub group III) is the most important viral pathogen on tomato transmitted by Bemisia tabaci. The disease incidence is correlated with the size of the $B$. tabaci population and attributed to the failure of the crop. Several weed hosts occurring in nature serve as reservoirs of inoculums both, virus and vector were reported to be the major contributors of the ToLCV inoculums for the outbreak of disease. Therefore eco-friendly and sustainable management strategies are urgently needed for the diverse biotypes of whiteflies that plague crops in different geographical and crop production environments. Endosymbiotic bacteria have identified one such approach, which could be exploited for controlling agricultural pests, whiteflies and whitefly transmitted diseases (WTDs) due to their effect on the phenotypic characteristics, fitness of the host and are the focus of increasing research, in the search for possible pest management strategies.

\section{Occurrence of tomato Leaf Curl Virus (ToLCV)}

The natural occurrence of tobacco leaf curl virus was observed on tomato in India by 
Pruthi and Samuel (1939). Besides India, tomato leaf curl virus was also reported from Philippines, Somalia (Castellani et al., 1981), Sudan (Cowland, 1932), Srilanka (Shivanathan, 1963) Egypt (Nour Eldin et al., 1969). Czosnek and Laterrot (1997) used two DNA probes of tomato yellow leaf curl virus Israel isolate (TYLCV-ISR) for hybridization test conducted survey in 25 countries of the world based on the DNA and protein sequence comparison grouped all the isolates into three clusters representing three regions that is, Mediterranean / Middle East / Africa, India, the Far - East and Australia and The American.

Sita Ghimire et al., (2001) reported that ToLCV causes yield losses of 40 per cent or even higher have been reported in some areas like Risingpatan, Tanahun and Kudule, of western hills of Nepal. ToLCV incidence in the rain fed tomato growing belt of Akhnoor in Jammu ranging between 80.00 to 98.00 per cent (Krishna Kumar et al., 2004). Saha et al., (2014) documented that the disease incidence in sub-Himalayan West Bengal and Brahmaputra valley of Assam was 18-83 per cent and 14-71 per cent respectively. Incidence of tomato leaf curl virus disease in Madhya Pradesh varied from 70 to 80 per cent and its spread was rapid with the maximum temperature of 28.7 to $30.8^{\circ} \mathrm{C}$ and minimum temperature of $15.1-22.3^{\circ} \mathrm{C}, 2.0$ $\mathrm{mm}$ rainfall and maximum relative humidity of $88-91.30$ and 44.6 - 69.6 per cent respectively (Singh and Reddy,1993).

\section{Economic importance}

Tomato is very important crop in India as well as world as a whole. Tomato leaf curl virus disease was reported to be a serious disease on tomato throughout India. The disease tends to cause up to 75 per cent or more reduction in fruit yield and due to its devastating nature it has become a national problem (saikia, 1989). Sastry and Singh (1973) reported that ToLCV infected plants produced few fruits when infected within 20 days after planting and resulting up to 92.3 per cent yield loss. Plants infected 35 and 50 days after transplanting resulted in 74 and 22.9 per cent yield loss, respectively. Tomato leaf curl virus disease cause serious damage sometimes devastating tomato crops in more than 20 countries (Czosnek and Laterrot, 1997).

Major contributory factors for the emergence and spread of new Gemini virus diseases are the evolution of variants of the viruses (Varma and Malathi, 2003).

Reliable estimates of the economic impact of the $B$. tabaci species complex on worldwide agriculture have been difficult to obtain because of the extensive areas affected, the numbers of crops and ornamentals involved, and different monetary systems. Over the last three decades, B. tabaci has caused excessive annual crop losses. The impact of direct feeding and honeydew excreta that favours sooty mould production is factors that affect crop yield in both quantitative and qualitative terms. Increased control costs and reduced product marketability and profitability are also important factors.

The global spread of the polyphagous $B$. tabaci biotype 'B' as a 'hitch-hiker' on traded plant material is a major factor in the worldwide increase in whitefly transmitted diseases. Changes in agronomic practices, which have resulted in irrigated crops being grown for longer overlapping periods of growth of crops in monoculture, and an increase in resistance to insecticides, have also been given as reasons for B. tabaci and its associated viruses becoming major problems. B. tabci is a vector of 111 plant viruses recognized as species in the genera Begomovirus (Geminiviridae), Crinivirus 
(Closteroviridae), Carlavirus or Ipomovirus (Potyviridae) and in addition vector of many other named viruses that are either in the same genera or in unidentified genera.

\section{Molecular detection of ToLCV}

Tomato yellow leaf curl virus DNA was used as a probe to identify and analyses the virus related DNA in infected tomato plants and in the whitefly vector by PCR technique (Czosnek et al., 1989). Navto et al., (1992) amplified the genomic DNA molecule of an Israel; isolate of ToLCV and ToLCV infected Lycopersicon esculentum M-82 by polymerase chain reaction (PCR) using synthetic oligonucleotides complimentary to different regions of the viral genome as primers. PCR technique was employed for the identification and characterization of four tomato yellow leaf curl virus isolates of Egypt using specific primers of ToLCV-ICR (Israel isolate) (Nakhla et al.,1993). DNA extracts of tomato plants infected with ToLCV in field conditions and whitefly DNA were used for PCR amplification with specific primers. Amplified DNA was highly reproducible and confirmed the presence of TYLCV (Aref and Dong, 1996). Ramos et al., (1996) determined the nucleotide sequence of the virus and comparison of sequence data with other isolates ranged between 85.7 and 97.3 percent similarity.

There is wide genetic diversity of tomato infecting begomo viruses. A distinct ToLCV strain from Taiwan (ToLCV) by employing polymerase chain reaction was identified (Shimizu and Ikegami., 1999). Khan (2000) detected ToLCV both in its host Lycopersicon esculentum and vector $B$. tabaci by employing geminivirus specific degenerated primers by polymerase chain reaction (PCR). Chakraborty et al., (2003) reported the new monopartite strain of tomato leaf curl virus disease from Gujarat in North of India.

\section{Gemini viruses}

Gemini viruses are plant infecting DNA viruses having a small genome size $\sim 2.6-$ 3.0 kilo bases (kb) (Gutierrez, 2000). Viruses of the Geminiviridae family are insect transmitted and can infect both monocots and dicots (Gutierrez et al., 2004). One or two circular single stranded DNA genomes packaged within a geminate virion particle in Geminiviruse (Fauquet et al., 2003). The virion particle is approximately $18-30$ nanometers $(\mathrm{nm})$ in size and the single stranded DNA (ssDNA) (Gutierrez et al., 2004).

Based on genome organisation, host range and insect vectors Geminiviruses are divided into four different genera (Rybicki et al., 2000).These included Mastrevirus, Curtovirus, Topocuvirus and Begomovirus (Fauquet et al., 2008). The fourth genus is Begomovirus, of which the type species is Bean golden yellow mosaic (BGYMV) virus and tomato leaf curl virus ToLCV (Varma and Malathi, 2003).

\section{Begomo viruses}

The genus Begomo virus is the largest genus of the Geminiviridae family. They transmitted by whitefly and infect only dicotyledonous plants (Sawangjit et al., 2005). Majority of begomo viruses originating in the New World, mostly from the American continent, including the Caribbean islands, have a bipartite genome made up of two circular ssDNA molecules, DNA-A (2.6kb) and DNA-B (2.5-2.8 kb) (Gutierrez, 2000). Several others with monopartite genomes have been identified in the Old World (consisting of Asia along with the Indian subcontinent and Africa) (Navot et al., 1992). These viruses are spread by the whitefly, $B$. tabaci in a circulative and persistent manner. Currently 133 Gemini virus species were 
recognized officially, out of which 117 belong to the genus Begomo virus (Fauquet et al., 2008). Several of the most destructive viral diseases of the tomato crop belong to the family Gemini viridae. There are at a minimum, 57 different species of Gemini viruses most of them being begomo viruses that are able to infect tomato (Abhary et al., 2007). Amongst the tomato-infecting monopartite Gemini viruses, Tomato pseudocurly top virus (TPCTV) is the only affiliate of the genus Topocuvirus, while Tomato leaf roll virus(ToLRV) is a member of the genus Curtovirus, and all remaining other tomato infecting geminiviuses belong to the Begomovirus genus (Fauquet et al., 2008).

ToLCV is a major problem for tomato growing regions of Indian subcontinent as several new strains have been reported including New Delhi, Lucknow, Bengaluru, Varanasi, Vadodara and Gujarat. Indian ToLCV isolates are mostly monopartite (DNA-A) in nature with few isolates possessing bipartite (DNA-A and DNA-B) genome organization such as tomato leaf curl New Delhi virus (ToLCNDV) and tomato leaf curl Palampur virus (ToLCPalV) (Briddon etal., 2008).

\section{Origin and taxonomy of B. tabaci}

The genus Bemisia contains 37 species (Mound and Halsey, 1978). The evolutionary affiliations of the Bemisia taxa within the family Aleyrodidae suggest that $B$. tabaci may have originated in tropical Africa and was introduced quite recently into the Neotropics and southern North America. Some evidence also suggests that $B$. tabaci may be native to India or Pakistan (Brown et al., 1995).

\section{Biology of B. tabaci}

Eggs are pear-shaped with a pedicel spike at the base, about $0.2 \mathrm{~mm}$ long. Eggs are laid usually in circular groups, on the underside of leaves, with the broad end touching the surface and the long axis perpendicular to the leaf. They are anchored by a pedicel which is inserted into a fine slit made by the female in the tissues, and not into stomata, as in the case of many other aleyrodids. Eggs are whitish when first laid but gradually turn brown. Hatching occurs after 5-9 days at $30^{\circ} \mathrm{C}$ but, like many other developmental rates, this depends very much on host species, temperature and humidity.

The adult is about $1 \mathrm{~mm}$ long, the male slightly smaller than the female. The body and both pairs of wings are covered with a powdery, waxy secretion, white to slightly yellowish. The adult emerges through a "T"shaped rupture in the skin of the puparium and spreads its wings for several minutes before beginning to powder itself with a waxy secretion from glands on the abdomen. Copulation begins 12-20 $\mathrm{h}$ after emergence and takes place several times throughout the life of the adult. The life span of the female could extend to 60 days. The life of the male is generally much shorter, being between 9 and 17 days. Each female lays up to 160 eggs during her lifetime, although the B biotype has been shown to lay twice as many, and each group of eggs is laid in an arc around the female. Eleven to fifteen generations can occur within one year.

\section{Hosts of B. tabaci}

Until recently, B. tabaci was mainly known as a pest of field crops in tropical and subtropical countries: cassava (Manihot esculenta), cotton (Gossypium), sweet potatoes (Ipomoea batatas), tobacco (Nicotiana) and tomatoes (Lycopersicon esculentum). Its host plant range within any particular region was small, yet $B$. tabaci had a composite range of around 300 plant species within 63 families (Mound and Halsey, 1978). 
With the evolution of the highly polyphagous B biotype, B. tabaci has now become a pest of glasshouse crops in many parts of the world, especially Capsicum, Courgettes (Cucurbita pepo), cucumbers (Cucumis sativus), Hibiscus, Gerbera, Gloxinia, lettuces (Lactuca sativa), poinsettia (Euphorbia pulcherrima) and tomatoes (Lycopersicon esculentum). B. tabaci moves readily from one host species to another and is estimated as having a host range of around 600 species (Asteraceae, Brassicaceae, Convolvulaceae, Cucurbitaceae, Euphorbiaceae, Fabaceae, Malvaceae, Solanaceae etc. (Li et al., 2011).

\section{Biotypes of $B$. tabaci}

B. tabaci is considered a cryptic species complex or sibling species group comprises a large number of genetically variable populations, some of which were referred to as biotypes or haplotypes (Brown, 2010). While morphologically indistinguishable, members of this species complex differ on a molecular level and exhibit full or incomplete reproductive isolation due to reproductive incompatibility (Oliveira et al., 2001). In $B$. tabaci unfertilized eggs develop into male progeny and fertilized eggs produce the female progeny as it is haplodiploid. The species complex has been found to differ in host range ( $\mathrm{Xu}$ et al., 2011), insecticide resistance (Luo et al., 2010), virus transmission (Li et al., 2010), behavior (Wang et al., 2010), and interactions with viruses and host plants.

One-step multiplex real-time reverse transcription (RT)-PCR has been developed by Cavalieri et al., (2014) for the identification of Trialeurodes vaporariorum, two invasive species of the complex $B$. tabaci (MEAM1 and MED) and for the specific detection of Tomato chlorosis virus (ToCV) and Tomato infectious chlorosis virus (TICV) in whiteflies and plants.
Three biotypes were identified based on their morphological characteristics and RAPDPCR analysis. The anterior and posterior wax fringes of the $\mathrm{B}, \mathrm{Q}$ and $\mathrm{Cv}$ biotypes significantly differed from each other. Based on this morphological characteristic, the three biotypes can easily be distinguished in greenhouses and fields (Qiu et al., 2009). Genomic DNA RAPD-PCR band patterns also revealed differences between these biotypes using the H16 primer. Introduced whitefly species responsible for over half billion dollars damage to US agricultural production is morphologically indistinguishable from $B$. tabaci Genn. However, the use of PCR based DNA differentiation tests, allozymic frequency analysis, crossing experiments and mating behavior studies revealed that the introduced whitefly was found to be distinct species (Perring et al., 1993).

RAPD-PCR was used to identify the Bbiotype of whitefly $B$. tabaci and distinguished it from other biotypes and species of whitefly. The technique enables the use of alcohol preserved material as required by allozyme electrophoresis and demonstrates that eggs, juvenile stages and males or females can be used (De Barro and Driver, 1997).

\section{Spread and distribution of Begomo viruses and its vector $B$. tabaci}

Hajimorad et al., (1996) reported the presence of (ToLCV) the virus in tomato growing provinces of southern but not northern Iran. They observed that some isolates of (ToLCV) like geminiviruses from different parts of Iran differ in symptomatologically. Diversity in TLCBs in southern India has been apparent since the early 1980s when Reddy et al., (1981) reported that in a single tomato variety, TLCB isolates gave rise to five distinct symptom types. Variability was 
subsequently also found in the epitome profiles of TLCBs collected from Karnataka. With groupings suggesting that the tomato crop and some neighboring weed species were hosts to the same TLCB strains (Muniyappa et al., 1991).

Chowda Reddy et al., (2005) reported the diversity and distribution of begomoviruses infecting tomato in India. Total DNAs was extracted from leaves of 69 tomato plants and 34 weeds or neighbouring crops collected from all the major tomato producing areas of India. Eighty-one of the 103 samples were positive by PCRs using begomovirus genusspecific primers. Coat protein (CP) genes from 29 samples were PCR amplified, cloned and sequenced. Phylogenetic analyses of the $\mathrm{CP}$ sequences revealed five different tomato leaf curl begomovirus (TLCB) clusters each $<88$ per cent identity to the others. Four clusters represented known Indian TLCBs, whereas one cluster contained sequences originating from Haryana State with most identity $(89 \%)$ to the provisional Begomovirus species Croton yellow vein mosaic virus. One hundred and sixty mitochondrial cytochrome oxidase I (COI) sequences from eight countries have been analyzed to investigate the geographic origin and current genetic structure of Asia I cryptic species. Sixty different haplotypes were identified, with levels of genetic distances ranging from 0.001 to 0.021 (Hu et al., 2014). Polston et al., (1999) observed tomato leaf curl virus on tomato plants in a retail garden center. Infected tomato transplants were produced for retail garden centers throughout the state of Florida. Infected plants purchased and grown in and around acted as the ToLCV inoculums for near commercial nurseries and production fields. The transplants played an important role in the movement of this and other geminiviruses. On the basis of PCR analysis, all ToLCV isolates collected from different part of Korea they originated from the interspecies recombination between Mld[PT] ToLCV isolated from Portugal as a major parent and TYLCTHV-MM isolated from Myanmar as a minor parent (Kim et al., 2010).

\section{Transmission of Begomo viruses}

It is well known that Begomo viruses can not transmit by themselves. It requires some medium to infect one to another that is vector.

\section{Vector transmission}

B. tabaci is a well known plant virus vector, transmitting distinct virus genera in the families Geminiviridae, Closteroviridae, Comoviridae, Flexiviridae, and Potyviridae, and Luteoviridae (Brown, 1994). Of these, the geminiviruses (Genus Begomovirus) and closteroviruses (Genus Crinivirus) are the most economically significant in terms of the damage they cause, especially the tomato, bean and cassava. Tomato yellow leaf curl begomovirus (TYLCB) and Tomato leaf curl begomovirus (ToLCB) causes massive yield and quality losses for tomatoes. Begomo viruses has only one vector that is $B$. tabaci (Gottlieb et al., 2010) because of a chaperone GroEL protein that binds the virus particles and protects them from degradation in gut and hemolymph. Gennadius (1889) first identified the holotype specimen of whitefly Bemisia tabaci Genn. in tobacco from Greece. Insect classified under the order Homoptera, family Aleyrodidae and sub family Aleyrodinae reported as the only known vector of ToLCV (Castellani et al., 1981).

\section{Virus-vector relationships}

It is always important to understand Virusvector relationships to make proper management strategy and it is also true that for batter transmission and infection there should be strong Virus-vector relationships. 
Many are component there that influence the Virus-vector relationships.

\section{Number of $B$. tabaci required for transmission}

Varma (1955) was the first to report successful transmission of begomovirus by $B$. tabaci, which was later confirmed by Capoor and Ahmad (1975) and Jayashree et al., (1999). Single whitefly was able to transmit the virus with 30 per cent efficiency, which increased to 60 per cent when three whiteflies were caged on healthy tomato seedlings. This contrasts with the 1.6 per cent transmission rate reported by Capoor and Ahmad (1975). A 100 per cent efficiency of transmission was achieved with five (Muniyappa et al., 2003) and fifteen (Jayashree et al., 1999) whiteflies per test plant but Capoor and Ahmad (1975) noticed a maximum infection of only 77.3 per cent with 20 whiteflies.

\section{Acquisition access period (AAP)}

The whitefly $B$. tabaci with piercing and sucking type of mouth parts was reported to carry plant viruses on the stylet. The minimum acquisition and inoculation feeding period required by $B$. tabaci to transmit tomato leaf curl virus was found to be 30 minutes each. After acquisition the vector required $6 \mathrm{~h}$. to become viruliferous. Single whitefly was able to transmit the virus. The whiteflies remained infective throughout their life span and virus was not transmitted to the progeny of the whitefly (Reddy, 1981).

\section{Inoculation access period (IAP)}

Inoculation access period is critical and very important for any transmission. Mansour and Al Musa (1992) reported that single whitefly (B. tabacci) was able to transmit the virus (ToLCV). The minimum AAP and IAP were 60 minutes and 30 minutes respectively and latent period was $20-24 \mathrm{~h}$. The virus was retained by $B$. tabaci for 11 days.

\section{Plant age}

The age of the plant also play a important role in disease development. The number of sixweek-old plants that became infected with ToLCV was only 20 per cent, compared to 100 per cent for one-week-old plants (Muniyappa et al., 2003). The susceptibility of the tomato plants to ToLCV was inversely proportional to their age. A decreasing percentage of older age groups became infected and the plants required progressively longer time period to express symptoms.

\section{References}

Aref, N.M. and Dong, D.K.A. 1996. Biological and molecular diagnosis of three different symptoms of TYLC disease in open field. Ann. Agri. Sci., 41: 173-185.

Briddon, R.W., Brown, J. K., Moriones, E., Stanely, J., Zerbini, M. 2008. Recommendations for the classification and nomenclature of the DNA- $\beta$ satellites of Begomoviruses. Arch. Virol., 4: 763-781.

Brown, J.K. 1994. The status of Bemisia tabaci Genn. as a pest and vector in world agroecosystems. FAO Bull., 42. In press.

Brown, J.K. 2010. Bemisia: Bionomics and Management of a Global Pest. (P. A. Stansly and S. E. Naranjo, Eds.). Dordrecht: Springer Netherlands. 4: 211-234.

Brown, J.K., Frohlich, D.R. And Rosell, R.C. 1995. The sweetpotato or silverleaf whiteflies: biotypes of Bemisia tabaci or a species complex?, Ann. Rev. Entomol., 40: 511-534.

Capoor, S.P. And Ahmad, R.U. 1975. Yellow vein mosaic disease of field pumpkin 
and its relationship with the vector, Bemisia tabaci. Indian Phytopath., 28: 241-246.

Castellani, E., Nour, A.M. and Mohammed, M.I. 1981. Tomato leaf curl in Somalia Larriciamento foliane del pomodaro in Somalia. Annali della facolta do Scienze Agrarie della, Universita dequistudi Ti. Torino, 12: 145-161.

Cavalieri, V., Manglli, A., Tiberini, A., Tomassoli, L. And Rapisarda, C. 2014. Rapid identification of Trialeurodes vaporariorum, Bemisia tabaci (MEAM1 and MED) and tomatoinfecting criniviruses in whiteflies and in tomato leaves by real-time reverse transcription-PCR assay. Bull. Insectol., 67(2): 219- 225.

Chakraborty, S., Pandey, P.K., Banerjee, M. K., Kalloo, G. and Fauquet, C.M. 2003, Tomato leaf curl Gujarat virus, a new begomovirus species causing a severe leaf curl disease of tomato in Varanasi India. Phytopathol., 93: 1485-1495.

Fauquet, C.M. 2003. Tomato leaf curl Gujarat virus, a new begomovirus species causing a severe leaf curl disease of tomato in Varanasi India. Phytopathol., 93: 1485-1495.

Chowda Reddy, R.V., Colvin, J., Muniyappa, V. and Seal, S. 2005. Diversity and distribution of begomoviruses infecting tomato in India. Arch. Virol., 150: 845867.

Cowland, J.W. 1932. In: Gezira Agriculture Research Service, Sudan.10: 324-332.

Crowder, D.W., Sitvarin, M.I. and Carriere, Y. 2010 Mate discrimination in invasive whitefly species. J. Insect Behavior, 23: 364-380.

Czosnek, H. and Laterrot, H. 1997. A worldwide survey of tomato yellow leaf curl viruses. Arch. Virol., 142: 1391-1406.

De Barro, P.J. and Driver, F. 1997. Use of RAPD-PCR to distinguish the biotype from other biotypes of Bemisia tabaci
(Genn.) (Hemiptera: Aleyrodidae). Australian J. Entomol., 36: 149-152.

Fauquet, C., Briddon, R., Brown, J., Moriones, E., Stanley, J., Zerbini, M. And Zhou, X., 2008, Geminivirus strain demarcation and nomenclature. Arch. Virol., 153: 783-821.

Gennadius, P. 1889. Diseases of tobacco plantations in the Trikonia, the Aleyorodid of tobacco. Ellnike Georgia, 5: $1-3$.

Gottlieb, Y., Fein, E.Z., Daube, N.M., Kontsedalov, S., Skaljac, M., Brumin, M., Sobol, I., Czosnek, H., Vavre, Fleury, F. and Ghanimi, M. 2010. The transmission efficiency of Tomato yellow leaf curl virus by the whitefly Bemisia tabaci is correlated with the presence of a specific symbiotic bacterium species. J. Virol., 84(18): 9310-9317.

Gutierrez, C. 2000. Geminiviruses and the plant cell cycle. Pl. Mol. Biol., 43: 763-

772.

Gutierrez, C., Ramirez-Parra, E., Castellano, M. M., Sanz-Burgos, A. P., Luque, A. And Missich, R. 2004. Geminivirus DNA replication and cell cycle interactions. Vet. Microbiol., 98: 111119.

Hajimorad, A., Kheyr Pour, V., Aalavj, A., Ahoonmanesh, M., Bahar, M., Rezaian, A. and Gronerborn, B. 1996. Identification of whitefly transmitted tomato yellow leaf curl geminivirus from Iran and a survey of its distribution with molecular probes. $\mathrm{Pl}$. Pests and Dis. Res. Inst., 45: 418-425.

$\mathrm{Hu}$, J., Chen, Jiang, Z.L., Nardi, F., Yang, T. Y., Jin, J. and Zhang, Z.K. 2014. Global haplotype analysis of the whitefly Bemisia tabaci cryptic species Asia I in Asia Mitochondrial DNA. Early Online, 1-10.

Jayashree, K., Pun, K.B. and Doraiswamy, S. 1999. Virus-vector relationship of 
yellow vein mosaic virus and whitefly (Bemisia tabaci) in pumpkin. Indian Phytopath., 52: 10-13.

Khan, J.A. 2000. Detection of tomato leaf curl geminivirus with vector Bemisia tabaci. Indian J. Expt. Biol., 38: 512 - 515.

Kim, S. H.,, Sung, O., Kyun, O.T., Sung, P.J., Chang, K.S., Hwan, K.S., Shik, K.Y., Kyu, H.J., Yun, S.S., Seo, P.K., Gu, L.H., Jae, K.K. and Won, C.C. 2010. Genetic diversity of Tomato yellow leaf curl virus (TYLCV) isolates tomatoinfecting in Korea.J. Virus Genes, 42: $117-127$.

Li, S.J., Xue, X., Ahmed, M.Z., Ren, S.X., Du, Y.Z., Wu, J.H., Cuthbertson, A.G. S. and Qiu, B.L. 2011. Host plants and natural enemies of Bemisia tabaci (Hemiptera: Aleyrodidae) in China. Insect Sci., 18: 101-120.

Luo, C., Jones, C.M., Devine, G., Zhang, F., Denholm, I. And Gorman, K. 2010. Insecticide resistance in Bemisia tabaci biotype Q (Hemiptera: Aleyrodidae) from China. Crop Prot., 29: 429-434.

Mound, L.A. and Halsey, S.H. 1978. Whitefly of the World: A systematic catalogue of the Aleyrodidae (Homoptera) with host plant and natural enemy data. Biosci., 22: 32-36.

Nour-Eldin, F., Mazyd, H. And Hassan, M. S., 1969, Tomato leaf curl virus disease. Agric. Res. Rev., 47: 49-54.

Oliveira, M.R.V., Henneberry, T.J. and Anderson, P. 2001. History, current status, and collaborative research projects for Bemisia tabaci. Crop Prot., 20: 709-723.

Perring, T.M., Cooper, A.D., Rodriguez, R.J., Farrar, C.A. and Bellows, T.S. 1993. Identification of whitefly species by genomic.

Polston, J.E., Goven, R.J. and Brown, L. 1999. Introduction of tomato leaf curl virus in Florida and implication of tomato for the spread of this and other geminiviruses of tomato. Pl. Dis., 83: 984-988.

Qiu, B., Chen, Y., Liu, L., Peng, W., Li, X., Ahmed, M, Z., Mathur, V., Du, Y. and Ren, S., 2009, Identification of three major Bemisia tabaci biotypes in China based on morphological and DNA polymorphisms. Prog. in Nat. Sci., 19: 713-718.

Ramos, P.L., Guerra, O., Dorestes, V., Ramirez, N., Riverabustamante, R. and Oramas, P. 1996. Detection of TYLCV in Cuba. Pl. Dis., 80: 1208.

Reddy, K.S. and Yaraguntaiah, R.C. 1981. Virus vector relationship $\mathrm{n}$ leaf curl disease of tomato. Indian Phytopath., 34: 310-313.

Rybicki, E.P., Briddon, R.W., Fauquet, C.M., Maxwell, D.P., Harrison, B.D., Markham, P.G. and Stanley, J. 2000. Geminiviridae: Virus Taxonomy. Seventh Report of the International Committee on Taxonomy of Viruses (P285- 297). New York: Academic Press, 6:285-297.

Saha, B., Saha, D., Biswas, K.K. and Saha, A. 2014. Distribution and molecular characterization of begomoviruses infecting tomato in sub-himalayan tarai region of West Bengal and Brahmaputra valley of Assam in northeast India. Indian Phytopath., 67(1): 92-96.

Saikia, A.K. and Muniyappa, V. 1989. Epidemiology and control of tomato leaf curl virus in Southern India. Trop. Agri., (Trinidad), 66: 350-354.

Sastry, K.S. and Singh, S.J. 1973. Assessment of losses in tomato by tomato leaf curl virus. Indian J. Mycol. Plant Pathol., 3: 50-54.

Sawangjit, S., Chatchawankanphanich, O., Pissawan, C., Attathom, T., Dale, J. and Attathom, S. 2005. Molecular characterization of tomato infecting begomoviruses in Thailand. Virus Res., 109: 1- 8. 
Shivanathan, P. 1963. The epidemiology of three diseases caused by whitefly borne pathogens. In: Plant virus epidemiology. (Eds. Plumb, R. T. and Thresh, J. M.), pp. 323-330.

Singh, S.J. and Reddy, M.K. 1993. Leaf curl virus disease of tomato and its management. Vatika from the Seed and Plant People, 2: 5-21.

Varma, A. and Malathi, V.G. 2003. Emerging geminivirus problems a serious threat to crop production. Ann. App. Biol., 142: 145-164.

Varma, P.M. 1955. Ability of the whitefy to carry more than one virus simultaneously. Curr. Sci., 24: 317-318.

Wang, Z., Shen, Z.R., Song, Y., Liu, H.Y. and

Li, Z.X. 2009. Distribution and diversity of Wolbachia in different populations of the wheat aphid Sitobion miscanthi (Hemiptera: Aphididae) in China. Eur. J. Entomol., 106: 49-55.

Xu, J., Lin, K.K. and Liu, S.S. 2011. Performance on different host plants of an alien and an indigenous Bemisia tabaci from China. J. of Appl. Entomol., 135: 771- 779 .

\section{How to cite this article:}

Ratan Das, Rajen Chowdhury, Ashutosh Singh and Susmita Sarkar. 2017. Diversity of Tomato Leaf Curl Virus (Tolcv), Bemisia tabaci and its Transmission. Int.J.Curr.Microbiol.App.Sci. 6(5): 78-87. doi: http://dx.doi.org/10.20546/ijcmas.2017.605.010 